\title{
IDENTIFIKASI KEMAMPUAN BERPIKIR KREATIF SISWA DENGAN METODE MIND MAPPING PADA PEMBELAJARAN FISIKA POKOK BAHASAN OPTIK DI SMA
}

\author{
${ }^{1)}$ Iriani Faizah Rofiqoh, ${ }^{1)}$ Subiki, ${ }^{1)}$ Aris Singgih Budiarso \\ ${ }^{1)}$ Program Studi Pendidikan Fisika FKIP Universitas Jember \\ Email: irianifaizah14@gmail.com
}

\begin{abstract}
Learning is a series of learning processes carried out by students to develop a student's knowledge, skill and attitude. Creativity is also required in the learning process. Creative thinking is the ability to solve problems in creating a success. One of the lessons that stressed creavity is the study of physics. Innovative learning can be done by selecting the methods of mind mapping presented in pictures and words. The mind mapping is the most effective and efficient way to input, store, and extract data from the brain. The study aims to identify students' creative thinking ability by using the mind mapping method in Jember high school students. The study is a qualitative and qualitative deitique carried out at Senior High School 4 Jember, Senior High School Ambulu, and Senior High School Jenggawah. Research tools involve the matter of creative thinking tests and the results of student sheets using the mind mapping method. Research shows that overall stages of the entire school being subjected to research, each indicator would be an average of 50-79. Within the criteria of a student's creativity can be categorized as moderate or creative enough.
\end{abstract}

Keywords : Identification, creative thinking ability, mind mapping, optics

\section{PENDAHULUAN}

Pada umumnya, pembelajaran fisika di sekolah masih menggunakan media dan metode yang konvensional, sehingga siswa kurang memiliki kesempatan untuk menganalisis fenomena alam yang terjadi di sekitar dengan konsep fisis dari materi fisika dan juga siswa akan mengalami kesulitan memahami materi fisika. Kemampuan berpikir siswa di Indonesia digambarkan bahwa kemampuan memahami lebih tinggi dibanding dengan kemampuan menerapkan dan menalar (Rofiah, 2013). Hal tersebut dapat diartikan bahwa kurangnya pemahaman siswa serta metode dan media mengajar guru yang masih konvensional akan mempengaruhi kerangka berpikir dan hasil belajar siswa yang tidak sesuai dengan indikator pencapaiannya. Pada kurikulum 2013, fisika merupakan satu dasar mata pelajaran yang didapat di SMA dan diadakan pertemuan setiap minggunya. Menurut Giancoli, (2014) fisika merupakan ilmu yang mempelajari tentang tingkah laku dan stuktur materi yang gejalanya sering terjadi dalam kehidupan sehari-hari. Fisika mempelajari fenomena atau gejala alam dengan proses yang dimulai dari pengamatan, pengukuran, analisis dan penarikan kesimpulan.

Berdasarkan hasil wawancara dengan guru fisika kelas XI di SMAN Ambulu, menunjukkan bahwa fisika adalah pelajaran yang sulit dan kurang menarik perhatian siswa. Salah satu materi yang dianggap sulit oleh siswa adalah materi Optik. Guru fisika menyatakan bahwa pada materi ini beberapa 
siswa belum tuntas. Siswa mengalami kesulitan belajar fisika dalam menyelesaikan permasalahan pada soal dan juga kesulitan memahami konsep dan rumus. Dalam menyelesaikan soal, siswa masih terpaku dengan cara yang dilakukan oleh guru. Sehingga siswa kurang mengeksplor kemampuan berpikirnya dalam menyelesaikan soal secara mandiri.

Kreativitas siswa juga dituntut dalam proses pembelajaran. Sejauh ini kreativitas siswa belum mendapat perhatian dalam proses pembelajaran terutama pada mata pelajaran ilmu fisika. Kreativitas siswa yang kurang diperhatikan dan diapresiasi dalam proses pembelajaran ini menyebabkan siswa tidak mau melakukan sesuatu hal yang baru. Padahal kreatif bukan hanya menciptakan sesuatu produk saja, melainkan kemampuan menciptakan sebuah solusi yang tidak terpaku pada satu jawaban. Berpikir kreatif perlu dikembangkan, dilatih, dan ditingkatkan mulai dari pendidikan pra sekolah sampai perguruan tinggi. Fakta dalam lapangan menurut Munandar (dalam Darusman, 2014), pendidikan di sekolah lebih berorientasi pada pengembangan intelegensi (kecerdasan) daripada pengembangan kemampuan kreativitas siswa, sedangkan dalam pendidikan keduanya sangat penting untuk keberhasilan proses pembelajaran.

Pada pembelajaran fisika juga bertujuan untuk meningkatkan keterampilan berpikir kreatif dan keterampilan proses siswa. Oleh karena itu, pemilihan media dan metode pembelajaran dalam menyusun kegiatan belajar juga sangat penting. Pada jaman sekarang telah banyak media dan metode yang menarik untuk siswa. Dengan memilih media dan metode yang tepat, maka akan menarik minat siswa dalam belajar fisika. Menurut Permatasari, et al (2013) pembelajaran yang inovatif dapat dilakukan dengan memilih metode mind mapping yang disajikan dalam bentuk gambar dan kata.
Swadarma (dalam Rahmawati, 2014) mind mapping juga dapat membantu menyusun dan menyimpan informasi yang diinginkan siswa dengan cara yang alami dan bersifat unik. Sesuatu yang bersifat unik akan lebih diingat siswa. Sedangkan menurut Widura (2008) mind mapping merupakan cara paling efektif dan efisien untuk memasukkan, menyimpan, dan mengeluarkan data dari otak.

Berdasarkan beberapa penelitian sebelumnya yang dilakukan oleh Wachidah dan Wasis (2015), menyimpulkan bahwa penerapan metode mind mapping pada materi alat-alat optik menunjukkan hasil yang sangat baik. Siswa mulai tertarik dalam membuat mind mapping dikarenakan metode ini mempermudah siswa dalam memahami materi, lebih bisa berkreasi, dan pembelajaran menjadi lebih menarik. Widyastuti (dalam Wachidah dan Wasis, 2015) menyatakan bahwa mind mapping dapat mempermudah dalam berkonsentrasi, membantu otak berpikir secara teratur, dan membebaskan ide-ide atau imajinasi sehingga membebaskan kreativitas siswa dalam pembelajaran. Penelitian lain yag dilakukan oleh Darusman (2014), peningkatan kemampuan berpikir kreatif siswa pada proses pembelajaran menggunakan mind mapping lebih baik daripada dengan cara konvensional.

Berdasarkan permasalahan yang diuraikan di atas, maka peneliti mencoba satu cara untuk meningkatkan kualitas pembelajaran fisika menggunakan metode mind mapping yang merujuk pada peningkatan kemampuan berpikir kreatif fisika di sekolah.

\section{METODE}

Penelitian ini menggunakan penelitian deskriptif. Penelitian ini dilakukan untuk mengetahui tingkat kemampuan berpikir kreatif siswa dengan menggunakan metode 
mind mapping pada siswa SMA. Penelitian ini dilaksanakan di SMAN 4 Jember, SMAN Ambulu, dan SMAN Jenggawah. Penentuan tempat penelitian menggunakan metode purpose sampling area, artinya daerah sengaja dipilih berdasarkan tujuan, waktu, tenaga dan biaya yang terbatas. Pemilihan tempat penelitian ini berdasarkan pada pertimbangan: (1) SMAN 4 Jember, SMAN Ambulu, dan SMAN Jenggawah bersedia untuk dijadikan sebagai tempat penelitian, (2) SMAN 4 Jember, SMAN Ambulu, dan SMAN Jenggawah menerapkan kurikulum 2013 edisi setelah revisi sehingga materi penelitian sesuai dengan kurikulum yang diterapkan di sekolah, (3) Penelitian yang serupa belum pernah dilakukan di sekolah tersebut.

Prosedur yang digunakan dalam penelitian ini terbagi dalam 2 tahap. Tahap pertama adalah tahap persiapan yaitu menentukan tema penelitian, menentukan sekolah yang akan digunakan untuk penelitian, mengumpulkan data, menyusun instrumen penelitian, melakukan pengecekan instrumen penelitian. Tahap kedua yaitu melakukan tes kemampuan berpikir kreatif dengan membuat catatan menggunakan metode mind mapping yang telah dijelaskan, memberikan soal uraian tes kemampuan berpikir kreatif siswa, mengidentifikasi hasil tes kemampuan berpikir kreatif berdasarkan indikator penilaian, mengklasifikasikan tingkat kemampuan berpikir kreatif siswa, dan menarik kesimpulan.

Teknik pengumpulan data dengan tes uraian dan tes pembuatan mind mapping. Pada tes uraian, setiap soal memiliki kategori aspek masing-masing. Soal nomor 1 tergolong aspek fluency, soal nomor 2 tergolong aspek flexibility, soal nomor 3 tergolong aspek originality, dan soal nomor 4 tergolong aspek elaboration. Pada tes pembuatan mind mapping juga memiliki kategori aspek masing-masing. Kata kunci yang digunakan tergolong aspek fluency, tingkat cabang mind mapping tergolong aspek flexibility, desain warna mind mapping tergolong aspek originality, dan kelengkapan materi mind mapping tergolong aspek elaboration. Analisis data kualitatif untuk menerjemahkan data kuantitatif dan memberikan predikat. Deskripsi kreativitas siswa selama pembelajaran fisika merupakan penjelasan kriteria nilai kemampuan berpikir kreatif siswa. Nilai kreativitas akan dihitung dengan rumus sebagai berikut:

$$
\mathrm{NP}=\frac{\sum \text { skor yang diperoleh }}{\sum \text { skor maksimum }} \times 100 \%
$$

(Sari, 2015)

Selanjutnya untuk menentukan kategori kemampuan siswa berdasarkan indikator berpikir kreatif yang dibedakan menjadi tiga yang sesuai dengan tabel 1 berikut:

Tabel 1 Kriteria Ketercapaian Kreativitas Siswa

\begin{tabular}{cc}
\hline Kriteria & Kategori \\
\hline $80-100$ & Tinggi \\
\hline $51-79$ & Sedang \\
\hline$<50$ & Rendah \\
\hline
\end{tabular}

(Sari, 2015)

Setelah menentukan kategori kemampuan siswa berdasarkan indikator berpikir kreatif, selanjutnya membuat perjenjangan kemampuan berpikir kreatif sesuai dengan tabel 2 sebagai berikut:

Tabel 2 Peringkat Kreativitas Belajar

\begin{tabular}{cl}
\hline Tingkat & \multicolumn{1}{c}{ Karakteristik } \\
\hline $\begin{array}{c}\text { Tingkat } 4 \\
\text { (Sangat }\end{array}$ & $\begin{array}{l}\text { Siswa mampu menunjukkan } \\
\text { Kreempat aspek berpikir }\end{array}$ \\
kreatif \\
\hline Tingkat 3 & $\begin{array}{l}\text { Siswa mampu menunjukkan } \\
\text { (Kreatif) }\end{array}$ \\
ketiga aspek berpikir kreatif \\
\hline Tingkat 2 & Siswa mampu menunjukkan \\
(Cukup & kedua aspek berpikir kreatif \\
Kreatif) & \\
\hline Tingkat 1 & Siswa mampu menunjukkan \\
(Kurang & satu aspek berpikir kreatif \\
\hline
\end{tabular}




\begin{tabular}{cl}
\hline Tingkat & \multicolumn{1}{c}{ Karakteristik } \\
\hline Kreatif) & \multicolumn{1}{c}{} \\
\hline Tingkat 0 & $\begin{array}{l}\text { Siswa tidak mampu } \\
\text { menunjukkan keempat aspek } \\
\text { (Tidak Kreatif) } \\
\end{array}$ \\
\hline
\end{tabular}

(Siswono dalam Mufidah, 2014)

\section{HASIL DAN PEMBAHASAN}

Penelitian ini tidak memberikan perlakuan khusus kepada siswa, akan tetapi peneliti hanya mengadakan tes tertulis yaitu tes keterampilan berpikir kreatif dengan metode mind mapping. Subjek penelitian yang digunakan yaitu, salah satu kelas XI MIPA yang ada di SMAN 4 Jember, SMAN Ambulu, dan SMAN Jenggawah. Dalam penelitian ini, peneliti menuliskan sampel dengan kelas SMAN 4 Jember sebagai sekolah A, SMAN Ambulu sebagai sekolah $B$, dan SMAN Jenggawah sebagai sekolah C.

Berikut ini, analisis data kemampuan berpikir kreatif siswa di Sekolah A, Sekolah B, dan Sekolah C. Hasil penelitian yang dilakukan di kelas XI MIPA 6 sekolah A dengan jumlah 27 siswa. Diperoleh skor dan nilai kemampuan berpikir kreatif yang disajikan pada Gambar 1 sebagai berikut:

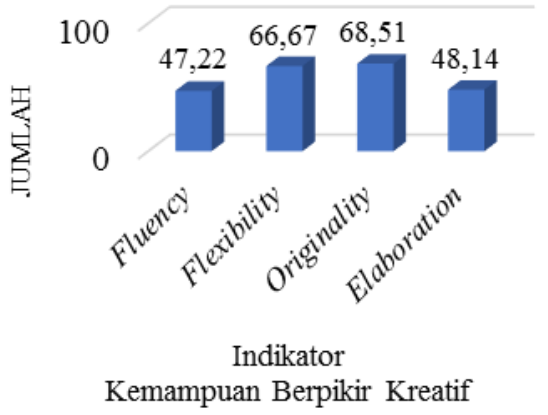

Gambar 1. Rata-rata Nilai Tes Kemampuan Berpikir Kreatif Siswa Kelas XI MIPA 6 di Sekolah A

Pada Gambar 1 diatas, diperoleh nilai tes kemampuan berpikir kreatif siswa dengan mengerjaan soal sebanyak 4 soal sebagai berikut: soal nomor 1 pada indikator fluency siswa memperoleh nilai rata-rata sebesar 47,22 tergolong kategori rendah. Soal nomor 2 pada indikator flexibility siswa memperoleh nilai rata-rata sebesar 66,67 tergolong kategori sedang. Soal nomor 3 pada indikator originality siswa memperoleh nilai rata-rata sebesar 68,51 tergolong kategori sedang. Soal nomor 4 pada indikator elaboration siswa memperoleh nilai rata-rata sebesar 48,14 tergolong kategori rendah. Hasil perolehan nilai kemudian dibuat perjenjangan kemampuan berpikir kreatif sesuai dengan Tabel 2 . Dimana pada penjenjangan kemampuan berpikir kreatif tersebut, siswa kelas XI MIPA 6 di sekolah A dikategorikan siswa cukup kreatif karena mampu menunjukkan dua indikator kemampuan berpikir kreatif dengan nilai kategori sedang dalam menylesaikan masalah. Indikator yang dimunculkan oleh siswa adalah pada indikator flexibility dan indikator originality.

Hasil penelitian pada pembuatan mind mapping yang dilakukan di kelas XI MIPA 6 di sekolah A diperoleh skor dan nilai kemampuan berpikir kreatif yang disajikan pada Gambar 2 sebagai berikut:

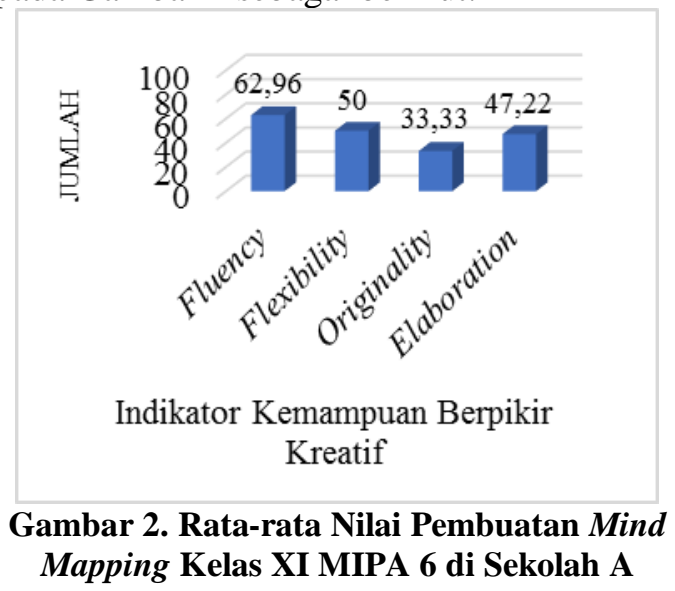

Berdasarkan Gambar 2 diperoleh skor dan nilai tes kemampuan berpikir kreatif siswa dengan membuat mind mapping. Terdapat 4 skor yang mengandung indikator 
untuk mengetahui skor kemampuan berpikir kreatif siswa. Pada indikator fluency (kata kunci) siswa memperoleh nilai rata-rata sebesar 62,96 tergolong kategori sedang. Indikator flexibility (tingkat cabang) siswa memperoleh nilai rata-rata 50 tergolong kategori rendah. Indikator orisinility (desain warna) siswa memperoleh nilai rata-rata 33,33 tergolong kategori rendah. Indikator elaboration (kelengkapan materi) siswa memperoleh nilai rata-rata 47,22 tergolong kategori rendah. Hasil perolehan nilai kemudian dibuat perjenjangan kemampuan berpikir kreatif sesuai dengan Tabel 2 . Dimana pada penjenjangan kemampuan berpikir kreatif tersebut, siswa kelas XI MIPA 6 di sekolah A dikategorikan siswa kurang kreatif karena mampu menunjukkan satu indikator kemampuan berpikir kreatif dengan nilai kategori sedang dalam pembuatan mind mapping. Indikator yang dimunculkan oleh siswa adalah pada indikator fluency.

Hasil penelitian yang dilakukan di kelas XI MIPA 1 sekolah B dengan jumlah 36 siswa. Diperoleh skor dan nilai kemampuan berpikir kreatif yang disajikan pada Gambar 3 sebagai berikut:

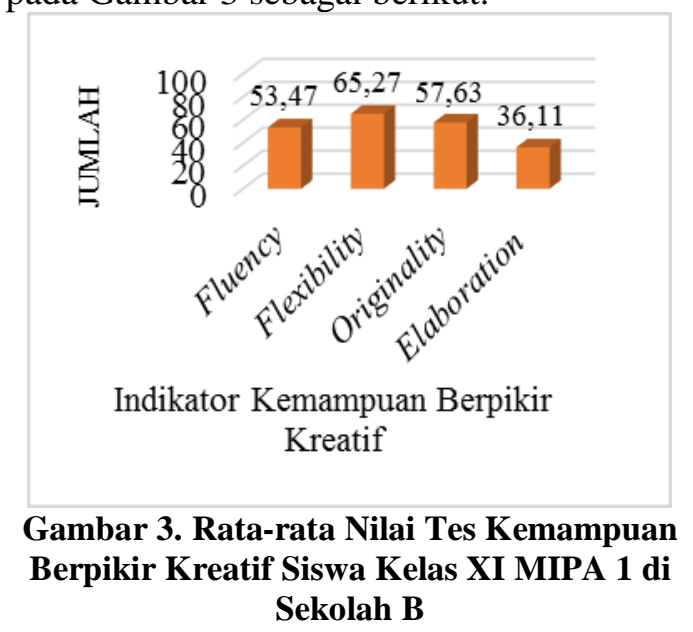

Pada Gambar 3 diatas, diperoleh skor dan nilai tes kemampuan berpikir kreatif siswa dengan mengerjaan soal sebanyak 4 soal sebagai berikut: soal nomor 1 pada indikator fluency siswa memperoleh nilai rata-rata sebesar 53,47 tergolong kategori sedang. Soal nomor 2 pada indikator flexibility siswa memperoleh nilai rata-rata sebesar 65,27 tergolong kategori sedang. Soal nomor 3 pada indikator originality siswa memperoleh nilai rata-rata sebesar 57,63 tergolong kategori sedang. Soal nomor 4 pada indikator elaboration siswa memperoleh nilai rata-rata sebesar 36,11 tergolong kategori rendah. Hasil perolehan nilai kemudian dibuat perjenjangan kemampuan berpikir kreatif sesuai dengan Tabel 2. Dimana pada penjenjangan kemampuan berpikir kreatif tersebut, siswa kelas XI MIPA 1 di sekolah B dikategorikan siswa kreatif karena mampu menunjukkan tiga indikator kemampuan berpikir kreatif dengan nilai kategori sedang dalam menyelesaikan masalah. Indikator yang dimunculkan oleh siswa adalah pada indikator fluency, flexibility dan originality.

Hasil penelitian pada pembuatan mind mapping yang dilakukan di kelas XI MIPA 1 sekolah B diperoleh skor dan nilai kemampuan berpikir kreatif yang disajikan pada Gambar 4 sebagai berikut:

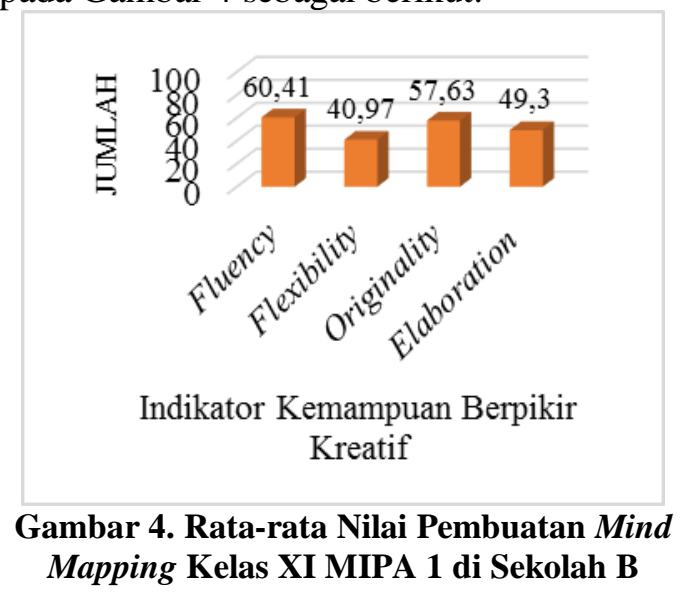

Berdasarkan Gambar 4 diperoleh skor dan nilai tes kemampuan berpikir kreatif siswa dengan membuat mind mapping. Terdapat 4 skor yang mengandung indikator 
untuk mengetahui skor kemampuan berpikir kreatif siswa. Pada indikator fluency (kata kunci) siswa memperoleh nilai rata-rata sebesar 60,41 tergolong kategori sedang. Indikator flexibility (tingkat cabang) siswa memperoleh nilai rata-rata 40,97 tergolong kategori rendah. Indikator orisinility (desain warna) siswa memperoleh nilai rata-rata 57,63 tergolong kategori sedang. Indikator elaboration (kelengkapan materi) siswa memperoleh nilai rata-rata 49,30 tergolong kategori rendah. Hasil perolehan nilai kemudian dibuat perjenjangan kemampuan berpikir kreatif sesuai dengan Tabel 2 . Dimana pada penjenjangan kemampuan berpikir kreatif tersebut, siswa kelas XI MIPA 1 di sekolah B dikategorikan siswa cukup kreatif karena mampu menunjukkan dua indikator kemampuan berpikir kreatif dengan nilai kategori sedang dalam pembuatan mind mapping. Indikator yang dimunculkan oleh siswa adalah pada indikator fluency dan orisinility.

Hasil penelitian yang dilakukan di kelas XI MIPA 4 sekolah $\mathrm{C}$ dengan jumlah 35 siswa. Diperoleh skor dan nilai kemampuan berpikir kreatif yang disajikan pada Gambar 5 sebagai berikut:

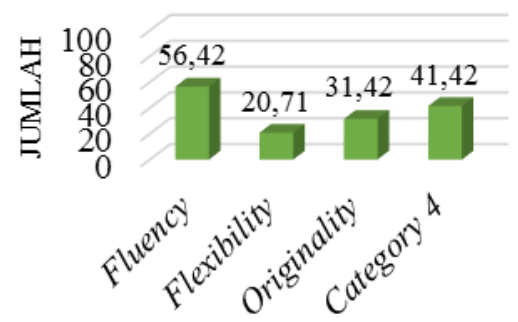

Indikator Kemampuan Berpikir Kreatif

Gambar 5. Rata-rata Nilai Tes Kemampuan Berpikir Kreatif Siswa Kelas XI MIPA 4 di Sekolah C

Pada Gambar 5 diatas, diperoleh skor dan nilai tes kemampuan berpikir kreatif siswa dengan mengerjaan soal sebanyak 4 soal sebagai berikut: soal nomor 1 pada indikator fluency siswa memperoleh nilai rata-rata sebesar 56,42 tergolong kategori sedang. Soal nomor 2 pada indikator flexibility siswa memperoleh nilai rata-rata sebesar 20,71 tergolong kategori rendah. Soal nomor 3 pada indikator originality siswa memperoleh nilai rata-rata sebesar 31,42 tergolong kategori rendah. Soal nomor 4 pada indikator elaboration siswa memperoleh nilai rata-rata sebesar 41,42 tergolong kategori rendah. Hasil perolehan nilai kemudian dibuat perjenjangan kemampuan berpikir kreatif sesuai dengan Tabel 2. Dimana pada penjenjangan kemampuan berpikir kreatif tersebut, siswa kelas XI MIPA 4 di sekolah C dikategorikan siswa kurang kreatif karena mampu menunjukkan satu indikator kemampuan berpikir kreatif dengan nilai kategori sedang dalam menyelesaikan masalah. Indikator yang dimunculkan oleh siswa adalah pada indikator fluency.

Hasil penelitian pada pembuatan mind mapping yang dilakukan di kelas XI MIPA 4 sekolah C diperoleh skor dan nilai kemampuan berpikir kreatif yang disajikan pada Gambar 6 sebagai berikut:

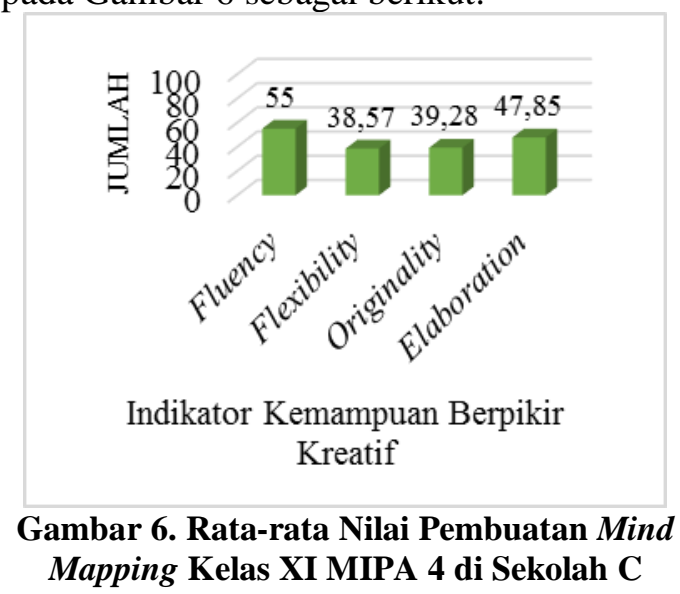

Berdasarkan Gambar 6 diperoleh skor dan nilai tes kemampuan berpikir kreatif siswa dengan membuat mind mapping. Terdapat 4 skor yang mengandung indikator 
untuk mengetahui skor kemampuan berpikir kreatif siswa. Pada indikator fluency (kata kunci) siswa memperoleh nilai rata-rata sebesar 55 tergolong kategori sedang. Indikator flexibility (tingkat cabang) siswa memperoleh nilai rata-rata 38,57 tergolong kategori rendah. Indikator orisinility (desain warna) siswa memperoleh nilai rata-rata 39,28 tergolong kategori rendah. Indikator elaboration (kelengkapan materi) siswa memperoleh nilai rata-rata 47,85 tergolong kategori rendah. Hasil perolehan nilai kemudian dibuat perjenjangan kemampuan berpikir kreatif sesuai dengan Tabel 2 . Dimana pada penjenjangan kemampuan berpikir kreatif tersebut, siswa kelas XI MIPA 4 di sekolah $\mathrm{C}$ dikategorikan siswa kurang kreatif karena mampu menunjukkan satu indikator kemampuan berpikir kreatif dengan nilai kategori sedang dalam pembuatan mind mapping. Indikator yang dimunculkan oleh siswa adalah pada indikator fluency.

\section{SIMPULAN DAN SARAN}

Berdasarkan hasil analisis dan pembahasan mengenai kemampuan berpikir kritis pada bab sebelumnya dapat disimpulkan bahwa: kemampuan berpikir kreatif siswa menggunakan mind mapping pada materi optik pada siswa SMA di Jember, dari keseluruhan tahap yang dilakukan seluruh sekolah yang dijadikan objek penelitian tiap indikatornya mendapat nilai kreiteria rata-rata 50-79. Dalam kriteria ketercapaian kreativitas siswa dapat dikategorikan sedang.

Berdasarkan penelitian dan hasil analisis data kemampuan berpikir kreatif yang telah dilakukan, maka saran yang dapat diberikan oleh peneliti sebagai berikut: penulis berharap guru sebaiknya memilih metode pembelajaran yang cocok dengan siswa sehingga dapat membantu meningkatkan kemampuan berpikir kreatif siswa. Dan guru juga sebaiknya melibatkan siswa secara aktif dalam proses pembelajaran dan lebih banyak menggunakan latihan menjawab soal. Bagi peneliti lain, dapat dijadikan penelitian yang serupa menggunakan materi, metode, dan instrumen yang berbeda.

\section{DAFTAR PUSTAKA}

Darusman, Rijal. 2014. Penerapan Metode Mind Mapping (Peta Pikiran) Untuk Meningkatkan Kemampuan Berpikir Kreatif Matematik Siswa SMP. Jurnal Ilmiah Program Studi Matematika. 3 (2).

Giancolli, Dauglas C. 2014. Fisika Edisi VII Jilid II. Jakarta: Erlangga.

Mufidah, I. 2014. Identifikasi Kemampuan Berikir Kreatif Siswa dalam pemecahan masalah matematika materi segiempat dan Segitiga Ditinjau dari Kemampuan Matematika Siswa Di Kelas VII SMPN 1 Driyorejo. Jurnal Ilmiah Pendidikan Matematika. 3(2): 113119.

Permatasari, Indhah, Jamzuri, \& Wahyuningsih, D. 2013. Penerapan Media Mind Mapping Program pada Model Pembelajaran Cotextual Teaching and Learning (CTL) untuk Meningkatkan Motivasi dan Hasil Belajar Fisika Siswa Kelas XI A.2 SMAN 4 Surakarta. Jurnal Pendidikan Fisika, 1(2), 28-33.

Rahmawati, M. M. E., dan Budiningsih, A. 2014. Pengaruh Mind Mapping Dan Gaya Belajar Terhadap Pemahaman Konsep Siswa Pada Pembelajaran IPA. Jurnal Inovasi Teknologi Pendidikan. 1 (2)

Rofiah, E., Aminah, N. S., dan Ekawati, E. Y. 2013. Penyusunan Instrumen Tes Kemampuan Berpikir Tingkat Tinggi Fisika pada Siswa SMP. Jurnal Pendidikan Fisika. 1(2): 17-22 
Sari, D. Novita. Sutikno, dan Matsuri. 2015. Pengaruh Pembelajaran Berbasis Proyek Terhadap Kreativitas Siswa Melalui Elektroskop Sederhana. Prosiding Seminar Nasional Fisika (E-Jurnal) 419 Januari 2015. Universitas Negeri Jakarta: 19-24.

Wachidah, U., dan Wasis. 2015. Penerapan Strategi Mind Mapping Untuk Meningkatkan Keterampilan Metakognitif Siswa Pada Materi AlatAlat Optik Kelas X SMA Negeri 1
Krembung. . Jurnal Inovasi Pendidikan Fisika. 4 (2), 33-39.

Widura, Sutanto. 2008. Brain Management Series For Learning Strategi Mind Mp, Langkah demi Langkah cara paling Mudah \& Benar Menggajar dan Membiasakan Anak menggunakan Mind Map untuk Meraih Prestasi. Jakarta : PT. Elex Media Komputindo. 